мотоцикле. 15 человек из 23 поврежденных при падении, получили травму в результате падения с высоты, 8 человек - в результате столкновения. Сочетанные травмы отмечались у 10 человек в результате автодорожных происшествий, у 8 человек - падения с высоты.

При ультразвуковом исследовании ушибы отмечались в основном у больных с изолированной травмой. При УЗИ у больных с закрытой травмой почек отмечены нарушения структуры и твердости ткани, а также характер и степень повреждений. Следует отметить, что при первичном УЗИ сочетанные травмы почек у 6 пациентов были выявлены в течение 12-24 часов.

Согласно полученным показателям четкость контуров отмечена у $76(89,4 \%)$ больных, неоднородность структуры паренхимы - у 66 (77,6\%), а увеличение размеров почек - у 48 (56,5\%). Для травмированных больных характерны такие эхографические показатели, как изменения в чашечно-лоханочной системе и четкость фиброзной капсулы, a также неоднородность структуры паренхимы. Расширение чашечно-лоханочной системы отмечалось у $10(11,7 \%)$ больных с разрывом паренхимы.

Разрывы по результатам УЗИ травмированных почек выявлены нами в 18,8\% случаях, но, в то же время, определить степень и глубину их распространения у каждого больного возможным не представилось, и было установлено лишь в 5,9\% случаях. Несмотря на это, мы считаем, что, хотя в ходе УЗИ и невозможно получить достаточно сведений о степени тяжести повреждения почки, однако данный метод незаменим в выявлении среди больных с тупой травмой почки тех, которым необходимо проведение рентгенологического исследования при уточнении диагноза.

1. Трофимова Е.Ю., Богницкая Т.В., Смоляр А.Н. Ультразвуковая диагностика забрюшинных кровоизлияний в ранние сроки после закрытой травмы живота // Ультразвуковая и функциональная диагностика, 2010, №5, с.14-19.

2. Труфанов Г.Е. Лучевая диагностика. Москва: ГЭОТАР-Медиа, 2012, 496 с.

3. Ультразвуковая диагностика: руководство для врачей. Под ред. Г.Е. Труфанова, В.В. Рязанова. СПб: ООО "ФОЛИАНТ", 2009, 439 с.

\title{
Hudiyev V.M., Kuliyev A.M. \\ Differentiated therapeutic tactics over and through condyle fractures of the hummers in children
}

\author{
Emergency Hospital, Sumgait,Azerbaijan \\ Research Institute of Traumatology and Orthopedics \\ (Azerbaijan, Baku)
}

doi: 10.18411/scienceconf-05-2019-22

idsp: scienceconf-05-2019-22

\section{Abstract}

The article analyzes the results of treatment of 155 patients with an over - and through condyle fractures of the humerus in children. The age of patients ranged from 1 to 15 years boys were 107 (69\%) and 48 (31\%) girls. All patients were examined clinically - radiologically With over-and through condyle fractures of the humerus in children more common household injuries aged 6 to 11 years. In boys, fractures were 2.2 times more common than in girls. The results were good in $98(63.2 \%)$ patients, satisfactory in $42(27.1 \%)$ patients, and unsatisfactory in $15(9.7 \%)$ patients. Analysis of the results after treatment showed that stable fixation allows to optimize the results of treatment and achieve good functional results, and does not lead to secondary deformation of the joint.

Key words: elbow joint, children, and through condyle fractures.

В литературе описано около 30 различных оперативных доступов к области локтевого сустава $[1,2]$. Многообразие способов лечения привело к широкому их 
применению без учета строгих показаний . При этом цена ошибки слишком высока ввиду технической трудности восстановления застарелого или неправильносросшегося перелома.

Цель исследования - предупреждение осложнений при лечении над- и чрезмыщелковых переломов плечевой кости у детей.

Материал и методы. $\quad$ Под нашим наблюдением с 2009 по 2015 г. находилось 155 детей в возрасте от 1 до 15 лет с над- и чрезмыщелковыми переломами плечевой кости у детей. Из них мальчиков было 107(69\%), девочек 48(31\%).

У мальчиков чаще встречается перелом плечевой кости в возрасте 8-10 лет, что связано с началом занятий активными играми.

Нами произведено ультразвуковое обследование локтевого сустава у 42 детей $(27,1 \%)$. Для более точной диагностики травматических повреждений ряду больных была выполнена компьютерная и магнитно-резонансная томографии.

$3(1,9 \%)$ больным произведена магнитно-резонансная томография. Компьютерная томография произведена 5 больным $(3,2 \%)$, позволившая более точно определить наличие перелома, линию излома и наличие сращения костных отломков. Эти исследования показывают также точность проведенной репозиции.

Результаты и обсуждение. Подавляющее большинство 70 больных $(36,1 \%)$ поступало в сроки до 33 часов, однако 85 (63,9\%) поступлений было в сроки от 1 до 28 дней после травмы с выраженным отеком в области локтевого сустава. Первичная помощь всем больным осуществлялась в травматологическом отделении. Из 155 больных поступивших в стационар 59 (38\%) детям первая помощь оказана костоправами, $33(21,3 \%)$ - в районных больницах, 10 (6,5\%) направлены из поликлиник, 40 (25,8\%) доставлены машинами скорой помощи и $13(8,4 \%)$ обратились сами.

У одного ребенка $1(0,75 \%)$ отмечалось сосудистое расстройство, но после открытой репозиции проходимость сосудов восстановилась, что оценено нами как сдавление артерии. Над-и чрезмыщелковые переломы плечевой кости у детей чаще встречаются в возрасте от 8 до 10 лет. У мальчиков эти переломы встречаются в 2,2 раза чаще, чем у девочек.

Из наблюдаемых нами 155 пациентов у 19 (12,3\%) применялось закрытая репозиция, у 62-х (40\%) - скелетное вытяжение. Фиксация фрагментов со спицами Кишнера произведена у 33 (21,3\%) больных.

При большой отечности в суставе сначала было использовано скелетное вытяжение, а после спадания отека была проведена закрытая репозиция и фиксация спицами Кишнера на скелетном вытяжении.

Метод открытой репозиции и остеосинтез металлическими спицами был использован у 41 (26,4\%) пациентов.

Показанием к открытой репозиции является опасность повреждения сосудистонервного пучка, нарушение периферического кровоснабжения, неудачная закрытая репозиция, большое смещение отломков, а также обращение больных в стационар через несколько суток после травмы.

У 98 пациентов применялись две спицы, у 55 - три спицы, у 1- одна спица, у 1 был использован один канюлированный винт $(0,6 \%)$.

При установлении диагноза должен быть учтен весь комплекс клинических признаков. 50\%-больных поступивших в отделение детской травматологии имели выраженный отек в области локтевого сустава, и гематому по передней поверхности сустава. Неврологические симптомы отмечены у 7 (4,5\%)-больных, из них у 3 (1,9\%) был поврежден лучевой нервов, у 1(0,6\%) срединный нерв а, локтевой нерв у 3 -х больных $(1,9 \%)$. Над- и чрезмыщелковый разгибательный перелом был у $67(43,2 \%)$ а сгибательный у 88 (56,8\%) детей.

Таким образом, анализ лечения 155 больных с над- и чрезмышелковыми переломами плечевой кости показывает что, у 19 больных с внутрисуставным открытым 
переломом без смещения (12,3\%) была использована гипсовая повязка, у 32 больных с внесуставным переломом $(20,65 \%)$ была использована одномоментная репозиция и фиксация гипсовой повязкой, у 41 больных с закрытым переломом и незначительным смещением было проведено скелетное вытяжение с одномоментной репозицией и наложением гипсовой повязки (26,3\%). У 62 больных с оскольчатыми переломами (40\%) было использовано скелетное вытяжение с гипсовой повязкой, у 1 больной $(0,6 \%)$ был использован остеосинтез с канюлированным винтом. Этот анализ подтверждает, что вовремя оказанная помощь в зависимости от характера и перелома у детей позволяет предотвратить появление вторичных осложнений.

При консервативном лечении нередко наблюдаются осложнения в виде неправильного сращения переломов, деформаций или контрактура локтевого сустава. Поэтому все над- и чрезмыщелковые переломы плечевой кости у детей в зависимости от степени смещения должны подвергаться точной репозиции. Уточнение показаний к лечению методом скелетного вытяжения следует проводить в зависимости от степени смещения отломков.

$$
* * *
$$

1. Marcheix P.S., Vacquerie V., Longis B., PeyrouP., Fourcade L., Moulies D. Distal humerus lateral condyle fracture in children: when is the conservative treatment a valid option? Orthop. Traumatol. Surg. Res.2011;97(3):304-307.

2. Morrey B.F. The elbow and its disorders. Philadelphia,London, New York: W.B. Saunders Comp.; 2000. $934 \mathrm{p}$.

\section{Krivoshchekov E.P. ${ }^{1}$, Alyapyshev G.S. ${ }^{2}$, Elshin E.B. ${ }^{3}$, Romanov V.E. ${ }^{4}$ Application of bioplastic, cellular and biological material for the healing of the wounds \\ ${ }^{1}$ Samara State Medical University (Russia, Samara) \\ ${ }^{2}$ Ulyanovsk State Hospital (Russia, Ulyanovsk) \\ ${ }^{3}$ Samara City Clinical Hospital 8 \\ (Russia, Samara) \\ ${ }^{4}$ Samara territorial fund of mandatory insurance \\ (Russia, Samara)}

doi: $10.18411 /$ scienceconf-05-2019-23

idsp: scienceconf-05-2019-23

One of the most pressing problems in surgery remains the treatment of patients with postoperative wound defects and nonhealing trophic ulcers of various localization. [1] The duration of treatment for such patients is long, and the cost is high. There is a wide range of different methods for treating wound defects. However, this problem is far from being resolved. [2] This determines the need to find new methods of treatment in this section of surgery.

The use of advances in the field of cell biology makes it possible to increase the possibilities of standard surgical techniques with the help of materials that can mimic the properties of replaceable biological structures. The main task is the selection of such combinations of cellular and non-cellular materials, which will allow to create effective, but not labor-intensive, express - products for wound healing.

Tissue engineering, as part of regenerative medicine, began its spread with the creation of tissue analogues of the skin. There are several methods for creating "artificial" skin.

The cultivated human derma "Dermagraft" is a product of fibroblast growth in a biodegradable medium. Production occurs within 2 weeks, after which fibroblasts are able to support the epithelialization process. After the end of cultivation - dermal fibroblasts secrete cytokines, glycosaminoglycans and growth factors, which favorably affects the healing of ulcers. 